\title{
Errata
}

\section{The Miltown era}

BioSocieties (2010) 5, 299. doi:10.1057/biosoc.2010.14

Andrea Tone, The Age of Anxiety: A History of America's Turbulent Affair with Tranquilizers. Basic Books, New York, 2009, US\$26.95, ISBN: 9780465086580

David Herzberg, Happy Pills in America: From Miltown to Prozac. Johns Hopkins University Press, Baltimore, MD, 2009, US\$45.00, ISBN: 9780801890307

Reviewed by Joseph E. Davis

Correction to: BioSocieties (2010) 5, 149-153. doi:10.1057/biosoc.2009.12

Due to an error that occurred during the correction process of the books forum, page 149 of Volume 5, the name of the reviewer was incorrectly given as Joseph E Davies, the correct spelling is Joseph E Davis. The typesetter wishes to apologise for this oversight.

\section{Ethics of neuroenhancement: A phantom debate}

BioSocieties (2010) 5, 299. doi:10.1057/biosoc.2010.13

Bettina Schone-Seifert, Davinia Talbot, Uwe Opolka and Johann S. Ach (eds.), Neuro-Enhancement. Ethik vor neuen Herausforderungen, mentis, Paderborn, 2009, £33.38, ISBN: 978-3897856028

Reviewed by Boris B. Quednow

Correction to: BioSocieties (2010) 5, 153-156. doi:10.1057/biosoc.2009.13

Due to a typesetting error, in the books forum, page 153 of Volume 5, the affiliation of Boris Quednow is incorrect; the correct affiliation is University Hospital of Psychiatry, University of Zurich, Switzerland. The typesetter wishes to apologise for this oversight. 